\title{
Fingerprint of volatiles from plant extracts based on SPME-GC-MS
}

\author{
Ezequias P. Siqueira*, Tânia M. A. Alves, Carlos L. Zani \\ Laboratório de Química de Produtos Naturais, Centro de Pesquisa Rene Rachou, Fundação Oswaldo Cruz, Av. \\ Augusto de Lima 1715, 30190-002, Belo Horizonte, MG, Brazil
}

\begin{abstract}
RESUMO: "Perfis gerados dos voláteis obtidos de extratos de plantas através da técnica MEFS-CG-EM" O Laboratório de Química de Produtos Naturais (LQPN) possui uma coleção ex situ de pequenas quantidades de extratos obtidos de componentes da biodiversidade para fins de bioprospecção. Esta coleção conta atualmente com cerca de 4000 extratos de mais de 1000 espécies distintas. Os extratos são usados na identificação de novos compostos bioativos que possam servir para o desenvolvimento de novas drogas contra as doenças negligenciadas como leishmanioses, doença de Chagas, malária e tuberculose. Após serem submetidos aos ensaios biológicos, os extratos que apresentaram atividade precisam ser preparados em uma quantidade maior a partir de recoletas dos vegetais, para permitir o isolamento dos seus componentes ativos. Neste ponto, o desenvolvimento de metodologias padronizadas que permitam comparar a composição dos extratos recém obtidos com a dos extratos originais são importantes para confirmação da identidade dos mesmos. Avaliou-se a metodologia de Micro-Extração em Fase Sólida, seguida de análise por Cromatografia Gasosa e Espectrometria de Massa (MEFS-CGEM). Foi usado o software AMDIS (Automatic Mass Spectral Deconvolution and Identification System) para armazenar e comparar os perfis gerados (fingerprint). Quarenta e seis amostras foram analisadas, onde foi possível inferir sobre os constituintes de cada amostra e traçar um perfil de composição e de componentes comuns. Foram analisados nove grupos de amostras, coletadas em diferentes períodos onde se estudou as variações sazonais ocorridas entre elas. Os resultados mostraram a viabilidade do uso desta ferramenta para monitorar a composição de extratos, permitindo avaliar alterações químicas durante a estocagem, a comparação entre extratos oriundos de coletas distintas, e na ocorrência de alguns componentes em diferentes extratos.
\end{abstract}

Unitermos: Cromatografia gasosa-espectrometria de massa (CGEM), perfil gerado, extratos vegetais, micro-extração em fase sólida (MEFS), AMDIS.

\begin{abstract}
The Laboratory of Chemistry of Natural Products has an ex situ collection of extracts from organisms of the biodiversity aiming at bioprospecting. Nowadays the collection has about 4000 extracts from 1000 different species. Extracts are used to identify new bioactive compounds that could be useful for developing new drugs against neglected diseases like leishmaniosis, Chagas disease, malaria and tuberculosis. After biologic assays, the bioactive extracts need to be prepared in larger quantity to allow isolation and characterization of the bioactive component. At this time, it is important to not only confirm the bioactivity of new extract but also check if its composition is similar to the old one. It was evaluated the ability of Solid Phase Microextraction and Gas Chromatography-Mass Spectrometry analysis (SPMEGC-MS). It was used the AMDIS (Automatic Mass Spectral Deconvolution and Identification System) software as tools to collect and to compare the chromatographic profiles of each extract (fingerprint). Forty six samples were analyzed, it was possible to infer from the composition of each sample and common compounds. Nine groups of samples, collected at different time, were analyzed and seasonal modifications between then could be elucidated. The results showed that this methodology can be used to monitor the composition of extracts, allowing to monitor chemical changes that may occur during storage periods and to investigate the occurrence of a determined component in different extracts.
\end{abstract}

Keywords: Gas chromatography-mass spectrometry (GCMS), fingerprint, vegetal extracts, solid phase microextraction (SPME), AMDIS.

\section{INTRODUCTION}

Plants, fungi, insects and other organisms from nature are a renowned source of bioactive compounds that can serve as drugs per se or as templates from which medicinal chemists can develop potent and selective 
drugs (Funari and Ferro, 2005; Albuquerque and Hanazaki, 2006). In spite of the recent development of new synthetic methodologies allowing the combinatorial synthesis of thousands of compounds around a common scaffold, many reviews and books show a plethora of data attesting the potential of natural products as a special source of unique pharmacophores for drug development. (Raskin et al., 2002; Bent and Ko, 2004; Khan et al., 2005; Barbosa-Filho et al., 2005; Amaral et al., 2006; Barbosa-Filho et al., 2006a,b,c; Funke and Melzig, 2006; Leitão et al., 2006; Lima et al., 2006; Julsing et al., 2006; Mayer and Gustafson, 2006; Paul et al., 2006; Floss, 2006; Wilkinson and Bachmann, 2006; Barbosa-Filho et al., 2007; Saúde-Guimarães and Faria, 2007).

Our group is bioprospecting Brazilian biomes for new bioactive natural compounds and thus we collected samples from more than 1000 different species and prepared more than 4000 extracts. The extracts are stored as solutions in DMSO $\left(20 \mathrm{mg} \cdot \mathrm{mL}^{-1}\right)$ at temperatures bellow $-20{ }^{\circ} \mathrm{C}$. Most of them were tested in one or more biochemical or cellular assays related to neglected diseases such as leishmaniasis, Chagas disease and tuberculosis. As the extracts are prepared in small quantities, when an active extract is detected, the plant material needs to be recollected and new extract prepared in sufficient amounts for isolation, structural elucidation, and in vitro and in vivo confirmatory bioassays. Sometimes, if the compound is unstable or occur in only minute amounts in the extracts, the process may have to be repeated several times. However, it is well known that seasonal variation, predation and other developmental and environmental factors can change significantly the bioactive compound contents in the plant or plant organ. This poses critical problems for recollection and there are chances that the active compound may not be present in the new extracts. It is not rare that a consistent biological activity in an extract cannot be reproduced once a new extract is prepared from the same species collected afterwards. It is also known that these extracts may contain hundreds of compounds and that changes in composition may occur due to oxidation, hydrolysis, photo-degradation, thermal instability, etc. Even freezethaw cycles can change the response of a biologic assay just by changing the solubility pattern of the components (Di and Kerns, 2006). In most cases, especially in large collections, these modifications are very difficult to be monitored. Thus, methodologies that can generate a fingerprint of each extract in large collections would be useful to detect stability of the same extract over time and similarity between extracts from recollections. Preferably, the method should be based on electronic storage, retrieval and analysis of the data.

Gas Chromatography hyphenised with Mass spectrometry (GC-MS) is a useful technique due to high separation power allied to the structural information by means of electronic impact mass spectrometry (EI-
MS). Thus, fingerprint can be performed in complex matrix analysis. Paúl et al., (2004) analyzed volatiles substances in Meum athamanticum, generating a profile of 46 components that were used to monitor seasonal and geographic chemical variations. Lu et al. (2006) used this methodology to create a fingerprint of Houttuynia cordata, a plant widely used to treat disease in China and produced by about 40 factories. They suggested that 15 components could be used as marker to fast identification and evaluations of the consistency from factory to factory and batch to batch.

In this study we describe the potential of SPME-GC-MS as a hyphenated technique to generate fingerprints of plants extracts that could allow to monitor the stability and to compare the composition of selected extracts based on identified and non-identified components.

\section{MATERIAL AND METHODS}

\section{Plant extracts}

The plants were collected in the region of Minas Gerais, Brazil, from 2001 to 2005. Extracts were prepared by maceration of fresh plant materials (leaves, fruits, flowers, bark, roots, etc) followed by immersion, for at least 7 days, in ethanol (P.A.) at room temperature, in the dark. The macerate was filtered and the solvent eliminated in a vacuum centrifuge at $40{ }^{\circ} \mathrm{C}$ to afford the crude extract. The extracts were dissolved in DMSO to $20 \mathrm{mg} \cdot \mathrm{mL}^{-1}$ solutions that were stored at $-20{ }^{\circ} \mathrm{C}$. The extracts used in this study were derived from plants species belonging to 13 families: Asteraceae, Fabaceae, Melastomataceae, Chrysobalanaceae, Rubiaceae, Bignoniaceae, Araliaceae, Orchidaceae, Araceae, Clusiaceae, Euphorbiaceae, Annonaceae, Icacinaceae.

\section{Collection of volatiles by SPME}

Fifty microliters from the $20 \mathrm{mg} \cdot \mathrm{mL}^{-1}$ solutions were transferred to a $2 \mathrm{~mL}$ glass vial and the solvent was removed under vacuum ( speedVac $^{\circledR}, \mathrm{SC} 250$ model, ThermoSavant, U.S.A) for 18 hours, $30{ }^{\circ} \mathrm{C}$ and 10 milibar. The vial was closed with a cap sealed with Teflon coated septum (Supelco, U.S.A) and placed in a heat block adjusted to $90^{\circ} \mathrm{C}$. A SPME fiber (PDMS/ DVB ${ }^{\mathrm{TM}} 65 \mu \mathrm{M}$, SUPELCO, U.S.A) was inserted by means of a manual holder through the septum and left in the headspace during 30 minutes. Immediately after that, the holder with the saturated fiber was analyzed by means of injection on $\mathrm{GC}$ injection port. Before use, the fiber was preconditioned at $230{ }^{\circ} \mathrm{C}$ during 30 minutes in the GC injector port.

\section{GC-MS analysis}

Gas Chromatography/Mass Spectrometry 
analyses were performed on a Shimadzu QP-5050A (SHIMADZU, JP) instrument, equipped with a PTE ${ }^{\mathrm{TM}}-5$ column ( $30 \mathrm{~m}, 0.25 \mathrm{~mm}, 0.25 \mu \mathrm{M}$, Supelco, USA), using helium as the carrier gas. The following conditions were employed for all analysis: helium at $22.3 \mathrm{~mL} \cdot \mathrm{min}^{-1}$; injector temperature maintained at $230{ }^{\circ} \mathrm{C}$; the oven at $80{ }^{\circ} \mathrm{C}$ during 3 minutes and then heated to $300{ }^{\circ} \mathrm{C}$ at $7{ }^{\circ} \mathrm{C}$. $\mathrm{min}^{-1}$, holding for 5 minutes at $300{ }^{\circ} \mathrm{C}$. The split valve was closed during the first minute of injection and then opened, with a 1:10 ratio. The mass detector was set to scan from 50 to 500 atomic mass unit, at a rate of 2 scans per second. Data acquisition and handling was done via CLASS 5000 Shimadzu software.

Analysis of the raw data using AMDIS software (Automated Mass Spectral Deconvolution and Identification System)

Raw data files were analyzed by Automated Mass Deconvolution and Identification System software (AMDIS), version 2.1, supplied by National Institute of Standards and Technology (NIST, USA). Retention Index (RI) in the range of 900 to 3000 was generated from analysis of a standard mixture containing hydrocarbons C9 to $\mathrm{C} 30$.

\section{Creation of the library}

The libraries were created after analyses and deconvolutions of the raw data. Few modifications on the parameters settings of the AMDIS software were done to permit best signal/noise ratio, especially on the sensitivity parameter. Each sample was analyzed and the data were saved individually as a *.msl library. Thus all samples produced several individual libraries

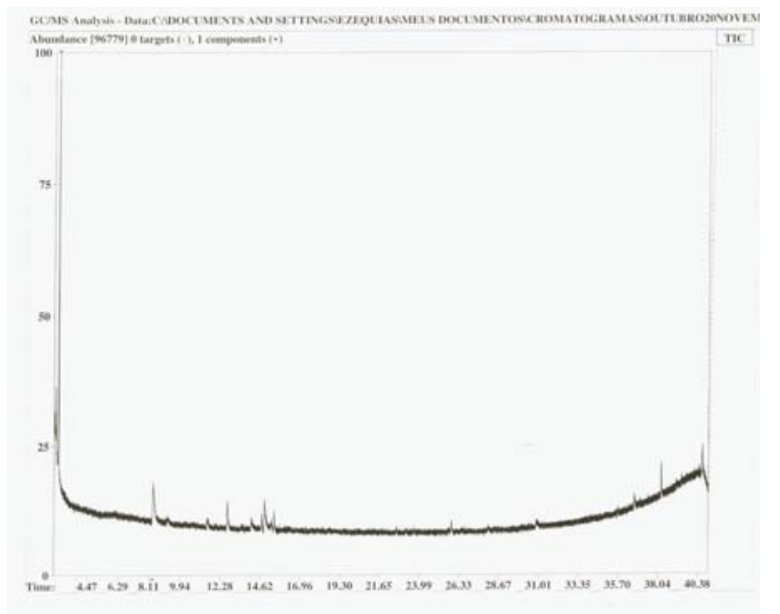

(A) that could be combined and used for several purposes. We could compare distinct sample or groups each other, to monitor a compound and its occurrence in a group of extracts, to monitor modifications due to seasonal process or to investigate about contaminations during storage.

\section{RESULTS AND DISCUSSION}

Preliminary studies to generate reproducible fingerprints were carried out by means of addition of different solvents in a dry crude extract and analysis of the solution produced. The results were not successful, generating few and weak peaks, even at high concentrations (Figure 1-A). On the other hand, using SPME resulted in a richer chromatogram (Figure 1-B), while being cleaner and faster way of sample preparation and injection. Furthermore, the reproducibility and robustness of the method is well described and it is a widely adopted methodology in quality control in food science (Bianchi et al., 2007; García-Llatas et al., 2007; Plutowska and Wardencki, 2007; Romeo et al., 2007), pesticides, environmental science and in volatiles substances in general (Pacolay et al., 2006; Balakrishnan et al., 2006; Kayali et al., 2006; Luan et al. 2006; Rodríguez et al., 2006; Kolb and Püttmann, 2006).

Among software available for data analysis, storage and handling, AMDIS was able to read the raw data file from the chromatograph and based on user selected parameters, perform the deconvolution of peaks based on the MS data. The AMDIS allowed the resolution of co-eluting components. Furthermore, after deconvolution, the software could, together with the NIST SEARCH software and library, perform an

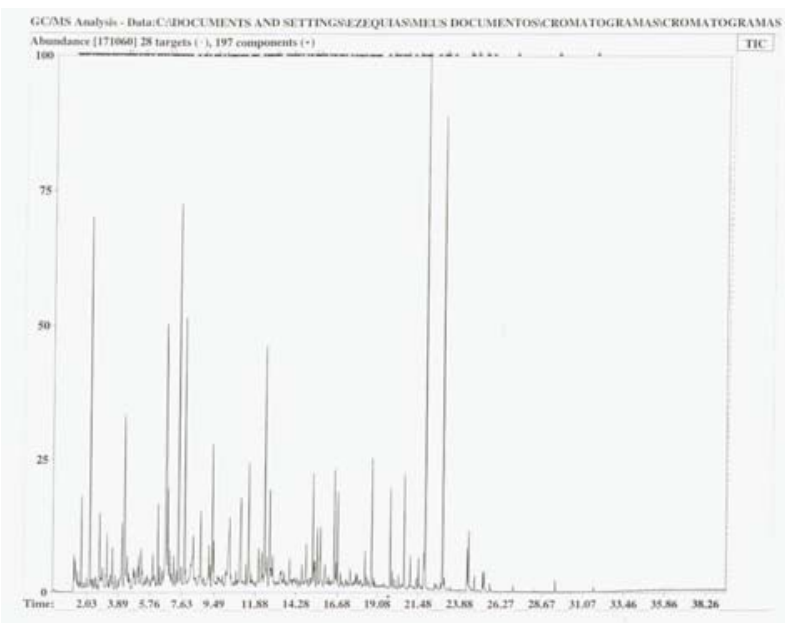

(B)

Figure 1. Comparison of chromatograms obtained from the same extract using two different sampling techniques and identical GC-MS conditions: (A) $1 \mu \mathrm{L}$ of ethyl acetate solution of crude extract using split 1:1; (B) Headspace capture of volatiles by SPME, splitless. 
Table 1. Conditions used in the experiments and volatiles components detected.

\begin{tabular}{|c|c|c|c|}
\hline Extract* & Plant Part used & Family & Number of Components detected \\
\hline 1 & Stem & Asteraceae & 101 \\
\hline 2 & Aerial parts & Asteraceae & 159 \\
\hline 3 & Root & Asteraceae & 52 \\
\hline 4 & Stem & Fabaceae & 41 \\
\hline 5 & Fruit & Fabaceae & 42 \\
\hline 6 & Stem & Fabaceae & 17 \\
\hline 7 & Flower & Melastomataceae & 41 \\
\hline 8 & Leaves & Melastomataceae & 42 \\
\hline 9 & Stem & Melastomataceae & 28 \\
\hline 10 & Leaves & Chrysobalanaceae & 53 \\
\hline 11 & Flower & Chrysobalanaceae & 78 \\
\hline 12 & Root & Rubiaceae & 50 \\
\hline 13 & Leaves & Rubiaceae & 47 \\
\hline 14 & Stem & Fabaceae & 51 \\
\hline 15 & Fruit & Fabaceae & 79 \\
\hline 16 & Root & Asteraceae & 111 \\
\hline 17 & Stem & Asteraceae & 84 \\
\hline 18 & Leaves & Asteraceae & 99 \\
\hline 19 & Stem & Bignoniaceae & 76 \\
\hline 20 & Leaves & Bignoniaceae & 97 \\
\hline 21 & Fruit & Bignoniaceae & 89 \\
\hline 22 & Stem & Rubiaceae & 53 \\
\hline 23 & Fruit & Rubiaceae & 44 \\
\hline 24 & Leaves & Rubiaceae & 72 \\
\hline 25 & Root & Rubiaceae & 54 \\
\hline 26 & Stem & Rubiaceae & 55 \\
\hline 27 & Leaves & Rubiaceae & 53 \\
\hline 28 & Flower & Melastomataceae & 108 \\
\hline 29 & Aerial parts & Melastomataceae & 140 \\
\hline 30 & Stem & Araliaceae & 49 \\
\hline 31 & Leaves & Araliaceae & 58 \\
\hline 32 & Whole plant & Orchidaceae & 108 \\
\hline 33 & Whole plant & Orchidaceae & 47 \\
\hline 34 & Leaves & Araceae & 139 \\
\hline 35 & Stem & Araceae & 60 \\
\hline 36 & Flower & Araceae & 59 \\
\hline 37 & Leaves & Fabaceae & 49 \\
\hline 38 & Stem & Fabaceae & 66 \\
\hline 39 & Flower & Asteraceae & 136 \\
\hline 40 & Leaves & Asteraceae & 112 \\
\hline 41 & Stem & Asteraceae & 127 \\
\hline $42 * *$ & Stem & Icacinaceae & 150 \\
\hline $43^{* * *}$ & Flower & Clusiaceae & 42 \\
\hline $44 * * *$ & Whole plant & Euphorbiaceae & 58 \\
\hline $45^{* * *}$ & Leaves & Fabaceae & 25 \\
\hline $46^{* * *}$ & Leaves & Annonaceae & 41 \\
\hline
\end{tabular}

* - Ethanolic extract; * - Dichloromethanic extract; *** - Aqueous extract. 
Table 2. Distribution of components between the 46 samples analyzed.

\begin{tabular}{|c|c|c|}
\hline Number of samples & Component detected & $\begin{array}{l}\text { Similarity index (\%) } \\
\text { according to Nist Library/ } \\
\text { Retention Index }\end{array}$ \\
\hline 41 & & $92 / 1271$ \\
\hline 37 & & $91 / 1993$ \\
\hline 36 & & $92 / 2162$ \\
\hline 36 & & $90 / 1845$ \\
\hline & & $90 / 1995$ \\
\hline 25 & & \\
\hline 17 & & \\
\hline 17 & & $80 / 1924$ \\
\hline 15 & & \\
\hline 14 & & $89 / 1539$ \\
\hline 12 & & \\
\hline 12 & & \\
\hline & & $87 / 1587$ \\
\hline
\end{tabular}

automatic search of experimental spectra. The most useful characteristic of AMDIS related to our problem was the possibility to save identified components in defined library that could be used to compare a new fingerprint with those stored in the library. This feature allows the comparison of entire chromatograms and also to identify in which extracts a single component was previously identified. The software offers advantage of comparing entire chromatograms in pairs.

At first time, analyses were performed to discern components between samples. By means of these analyses, it was possible to identify similar and no similar compounds and to characterize the chemical profile for each sample. The Table 1 shows the number of components in the analyzed extracts. All peaks were detected and deconvoluted by AMDIS and saved in the software library. Organic acids, ester, ketones, aldehydes, phenolics compounds, and terpenes were observed as the major chemical classes present in the samples. It was observed that nonanoic acid was the modal component, observed in $89 \%$ of the samples, Table 2 .

The analyses reveal that although some 
Table 3. Comparison between extracts from same origin but collected at different periods.

\begin{tabular}{cccccc}
\hline Group & $\begin{array}{c}\text { Extracts to be } \\
\text { compared }\end{array}$ & $\begin{array}{c}\text { Number of } \\
\text { components }\end{array}$ & $\begin{array}{c}\text { Number of common } \\
\text { targets }\end{array}$ & $\begin{array}{c}\text { Extract used as } \\
\text { library } \\
\text { (reference) }\end{array}$ & $\begin{array}{c}\text { Percent of } \\
\text { matches }\end{array}$ \\
\hline 1 & 2005 & 148 & 122 & 2933 & 82.4 \\
2 & 2933 & 138 & 103 & 2005 & 74.6 \\
& 2004 & 112 & 81 & 2934 & 72.3 \\
3 & 2934 & 91 & 77 & 2004 & 84.6 \\
& 2068 & 89 & 59 & 2903 & 66.3 \\
4 & 2903 & 148 & 90 & 2068 & 60.8 \\
& 2121 & 94 & 66 & 2884 & 70.2 \\
5 & 2884 & 91 & 69 & 2121 & 75.8 \\
& $257 \mathrm{~A} 1$ & 120 & 109 & $257 \mathrm{~B} 1$ & 91.0 \\
6 & $257 \mathrm{~B} 1$ & 150 & 125 & $257 \mathrm{~A} 1$ & 83.3 \\
& $257 \mathrm{~A} 2$ & 139 & 125 & $257 \mathrm{~B} 2$ & 89.9 \\
7 & $257 \mathrm{~B} 2$ & 158 & 129 & $27 \mathrm{~A} 2$ & 81.7 \\
& $257 \mathrm{~A} 3$ & 87 & 81 & $257 \mathrm{~B} 3$ & 93.1 \\
& $257 \mathrm{~B} 3$ & 119 & 88 & $257 \mathrm{~A} 3$ & 74.0 \\
& 2500 & 152 & 82 & 4057 & 54.0 \\
& 4057 & 157 & 85 & 2500 & 54.1 \\
& 2431 & 78 & 67 & 2964 & 86.0 \\
& & & 72 & 193 & 92.3 \\
& & & 68 & $183 \mathrm{~A}$ & 87.2 \\
& & & 67 & $183 \mathrm{~B}$ & 86.0 \\
\hline
\end{tabular}

components could be identified in several samples, the majority of the products were present in only few ones, resulting in some degree of uniqueness of the profiles, allowing for their distinction. In other words, each sample could be identified as a unique individual.

Nine groups of extracts pairs were analyzed to identify compounds among samples from same species but collected at different periods. It was possible to identify variations between pairs. None of the pairs matched up each other completely but a large number of compounds could be detected and, by means of cross linking comparison, it was possible identify at least 54 per cent of common components, group 8, Table 3 . It was possible to discern samples based only on chemistry profile. Although 54 per cent is not so high, 82 or 85 compounds were identified as common component in the sample. In general, this quantity is higher than the number of compounds described in the literature to perform quality control or fingerprint. Lu et al. (2006) suggested that only 15 components could be investigated as marker for quality control in Houttuynia cordata. Paúl et al. (2004) used 46 components to monitor seasonal modifications in Meum athamanticum.

\section{CONCLUSIONS}

Gas Chromatography hyphenised with Mass Spectrometry and SPME were important tools in the elucidation of the volatiles components in complex matrix, as natural products. Although only volatiles components could be analyzed, this methodology was important to the creation of fingerprint and monitoring of the samples using AMDIS software. This methodology was able to verify changes in compositions or degradations process in extracts and also perform confrontation between samples and distribution of the components between samples.

\section{ACKNOWLEDGMENTS}

Thanks to PAPES IV for financial support, FIOCRUZ/CNPq. We would like to thank Dr. Anita J. Marsaioli, Chemistry Institute at UNICAMP-SP, for hydrocarbon C9-C30 standard supplied to perform retention index. 


\section{REFERENCES}

Albuquerque UP, Hanazaki N 2006. As pesquisas etnodirigidas na descoberta de novos fármacos de interesse médico e farmacêutico: fragilidades e pespectivas. Rev Bras Farmacogn 16(Supl.): 678-689.

Amaral FMM, Ribeiro MNS, Barbosa-Filho JM, Reis AS, Nascimento FRF, Macedo RO 2006. Plants and chemical constituents with giardicidal activity. Rev Bras Farmacogn 16(Supl.): 696-720.

Balakrishnan VK, Terry KA, Toito J 2006. Determination of sulfonamide antibiotics in wastewater: A comparison of solid phase microextraction and solid phase extraction methods. J Chromatogr A 1131: 1-10.

Barbosa-Filho JM, Vasconcelos THC, Alencar AA, Batista LM, Oliveira RAG, Guedes DN, Falcão HS, Moura MD, Diniz MFFM, Modesto-Filho J 2005. Plants and their active constituents from South, Central, and North America with hypoglycemic activity. Rev Bras Farmacogn 15: 392-413.

Barbosa-Filho JM, Piuvezam MR, Moura MD, Silva MS, Lima KVB, Cunha EVL, Fechine IM, Takemura OS 2006a. Anti-inflammatory activity of alkaloids: A twenty-century review. Rev Bras Farmacogn 16: 109-139.

Barbosa-Filho JM, Medeiros KCP, Diniz MFFM, Batista LM, Athayde-Filho PF, Silva MS, Cunha EVL, Almeida JRGS, Quintans-Júnior LJ 2006b. Natural products inhibitors of the enzyme acetylcholinesterase. Rev Bras Farmacogn 16: 258-285.

Barbosa-Filho JM, Martins VKM, Rabelo LA, Moura MD, Silva MS, Cunha EVL, Souza MFV, Almeida RN, Medeiros IA 2006c. Natural products inhibitors of the angiotensin converting enzyme (ACE). A review between 1980-2000. Rev Bras Farmacogn 16: 421-446.

Barbosa-Filho JM, Nascimento-Júnior FA, Tomaz ACA, Athayde-Filho PF, Silva MS, Cunha EVL, Souza MFV, Batista LM, Diniz MFFM 2007. Natural products with antileprotic activity. Rev Bras Farmacogn 17: 141-148

Bent S, Ko R 2004.Commonly used herbal medicines in the United States: a review. Am J Med 116: 478-485.

Bianchi F, Careri M, Musci M, Mangia A 2007. Fish and food safety: Determination of formaldehyde in 12 fish species by SPME extraction and GC-MS analysis. Food Chem 100: 1049-1053.

Di L, Kerns EH 2006. Biological assay challenges from compound solubility: strategies for bioassay optimization. Drug Discov Today 11: 446-451.

Floss HG 2006. Combinatorial biosynthesis-Potential and problems. J Biotechnol 124: 242-257.

Funari CS, Ferro VO 2005. Uso ético da biodiversidade brasileira: necessidade e oportunidade. Rev Bras Farmacogn 15: 178-182.

Funke I, Melzig MF 2006. Traditionally used plants in diabetes therapy - phytotherapeutics as inhibitors of $\alpha$-amylase activity. Rev Bras Farmacogn 16: 1-5.

García-Llatas G, Lagarda MJ, Romero F, Abellán P, Farré $R$ 2007. A headspace solid-phase microextraction method of use in monitoring hexanal and pentane during storage: Application to liquid infant foods and powdered infant formulas Food Chem 101: 1078-1086.

Julsing MK, Koulman A, Woerdenbag HJ, Quax WJ, Kayser O 2006. Combinatorial biosynthesis of medicinal plant secondary metabolites medicinal plant. Biomol Eng 23: 265-279.
Kayali N, Tamayo FG, Polo-Díez LM 2006. Determination of diethylhexyl phtalate in water by solid phase microextraction coupled to high performance liquid chromatography. Talanta 695: 1095-1099.

Khan MTH, Ather A, Thompson KD, Gambari R 2005.Extracts and molecules from medicinal plants against herpes simplex viruses. Antivir Res 67: 107-119.

Kolb A, Püttmann W 2006. Methyl tert-butyl ether (MTBE) in finished drinking water in Germany. Environ Pollut 140: 294-303.

Leitão SG, Castro O, Fonseca EM, Julião LS, Tavares ES, Leo RRT, Vieira RC, Oliveira DR, Leitão GG, Martino V, Sulsen V, Barbosa YAG, Pinheiro DPG, Silva PEA, Teixeira DF, Lourenço MCS 2006. Screening of Central and South American plant extracts for antimycobacterial activity by the Alamar Blue test. Rev Bras Farmacogn 16: 6-11.

Lima MRF, Ximenes CPA, Luna JS, Sant'Ana AEG 2006. The antibiotic activity of some Brazilian medicinal plants. Rev Bras Farmacogn 16: 300-306

Lu HM, Liang YZ, Chen S 2006. Identification and quality assessment of Houttuynia cordata injection using GC-MS fingerprint: A standardization approach $J$ Ethnopharmacol 105: 436-440.

Luan TG, Yu KSH, Zhong Y, Zhou HW, Lan CY, Tam NFY 2006. Study of metabolites from the degradation of polycyclic aromatic hydrocarbons (PAHs) by bacterial consortium enriched from mangrove sediments. Chemosphere 65: 2289-2296.

Mayer AMS, Gustafson KR 2006. Marine pharmacology in 2003-2004: Anti-tumour and cytotoxic compounds. Eur J Cancer 42: 2241-2270.

Pacolay BD, Ham JE, Wells JR 2006. Use of solid-phase microextraction to detect and quantify gas-phase dicarbonyls in indoor environments. $J$ Chromatogr A 1131: 275-280.

Paul AT, Gohil VM, Bhutani KK 2006. Modulating TNF- $\alpha$ signaling with natural products. Drug Discov Today 11: 725-732.

Paúl PJ, Jiménez RG, Alonso MJP 2004. Essential oil composition of the leaves and stems of Meum athamanticum Jacq., from Spain. J Chromatogr A 1036: 245-247.

Plutowska B, Wardencki W 2007. Aromagrams - Aromatic profiles in the appreciation of food. Food Chem 101: 845-872.

Raskin I, Ribnicky DM, Komarnytsky S, Ilic N, Poulev A, Borisjuk N, Brinker A, Moreno DA, Ripoll C, Nir Yakoby N 2002. Plants and human health in the twenty-first century Trends Biotechnol 20: 522-531.

Rodríguez I, Calvo F, Quintana JB, Rubí E, Rodil R, Cela R 2006. Suitability of solid-phase microextraction for the determination of organophosphate flame retardants and plasticizers in water samples. $J$ Chromatogr A 1108: 158-165.

Romeo V, Ziino M, Giuffrida D, Condurso C, Verzera A 2007. Flavour profile of capers (Capparis spinosa L.) from the Eolian Archipelago by HS-SPME/GC-MS. Food Chem 101: 1272-1278.

Saúde-Guimarães DA, Faria AR 2007. Substâncias da natureza com atividade anti-Trypanosoma cruzi. Rev Bras Farmacogn 17: 455-465.

Wilkinson B, Bachmann BO 2006. Biocatalysis in pharmaceutical preparation and alteration. Curr Opin Chem Biol 10: 169-176. 